\title{
Empire. The concept and its problems in the historiography on the iberian empires in the Early Modern Age ${ }^{1}$
}

\author{
Christian Hausser ${ }^{1}$ and Horst Pietschmann ${ }^{2}$ \\ 1 Assistant Professor in Latinoamerican History, Instituto de Estudios Humanísticos 'Juan Ignacio Molina', Universidad de Talca, Chile, \\ 2 Emeritus Professor of Latin American History, Universität Hamburg, Germany \\ e-mail: chhausser@icloud.com,hpietschmann@t-online.de
}

Submitted: 1 January 2014. Accepted: 15 May 2014

\begin{abstract}
The article studies the more recent historiography about the Spanish and Portuguese empires. It identifies several types of interpretations and the use of 'empire' as a concept in different contexts, academic traditions and epochs. In doing so, it points to the achievements made and to the gaps that still exist, especially in the context of Renaissance humanism. It is the article's goal to facilitate a dialogue between academics about a topic that in the last decade or so has revealed crucial for the study of Ibero-American as well as for European history.
\end{abstract}

KEYWORDS: Spain; Portugal; empire; Early Modern History; concept; historiography

Citation / Cómo citar este artículo: Hausser, Christian and Pietschmann, Horst (2014). "Empire. The concept and its problems in the historiography on the iberian empires in the Early Modern Age". Culture \& History Digital Journal, 3(1): e002. doi: http://dx.doi.org/10.3989/chdj.2014.002

\begin{abstract}
RESUMEN: Imperio. El concepto y sus problemas en la historiografía sobre los imperios ibéricos en la Edad Moderna.- El trabajo analiza la historiografía más reciente acerca de los imperios español y portugués. Identifica líneas de interpretación y el uso del concepto de 'imperio' en contextos, tradiciones académicas y épocas distintas. De esa manera apunta a los logros alcanzados y a las lagunas existentes, particularmente en el marco del humanismo renacentista. El objetivo es contribuir a facilitar el diálogo dentro la investigación acerca de un tema que en los últimos años ha sido uno de los más estudiados en el marco de la historia ibero-americana y europea.
\end{abstract}

PALABRAS CLAVE: España; Portugal; imperio; Edad Moderna; conceptos; historiografía

Copyright: (C) 2014 CSIC. This is an open-access article distributed under the terms of the Creative Commons AttributionNon Commercial (by-nc) Spain 3.0 License.

\section{INTRODUCTION}

The concept of "empire" has been applied over the past 15 years or so to all kinds of extended political formations, past and present, whether they were called "empire" or were governed by an "emperor," or were only notable for their great political, economic-financial, military or religious-ideological power. Despite the widespread use of the term, however, the cases of Spain and Portugal are particularly problematic to define, as they cover different timeframes and regions and encompass virtually all possible defining criteria, spread out over different times. In introducing the problem, it therefore seems advisable to critically review the devel- opment of the concept in historiography, given that rather disparate historiographic traditions have played a part in this trajectory, and, above all, because these were preceded by a humanist debate in the $15^{\text {th }}$ century referring to the Holy Roman Empire that could have been reflected in the expansion and configuration of the Iberian trans-Atlantic empires.

\section{DEBATES SURROUNDING THE HISTORIOGRAPHY OF THE SPANISH EMPIRE}

The concept of 'Spanish empire' was introduced in the 1960 s by the British historiographer J. H. Parry (1940: 75ff., 1966) shortly after Helmuth G. Koenigs- 
berger had affirmed categorically that the concept of 'empire' should be limited in the Spanish case to the time of Charles V, as Philip II did not know how to redefine 'empire' after the title had fallen into the hands of the Austrian Habsburgs (Koenigsberger 1958, Koenigsberger 1968). 'Empire' was at first reduced to a debate within historiography written in English, through which it was disseminated later, though more quickly, in the English-speaking world than in continental Europe and Latin America.

One reason for its reduction to the English-speaking world was that the French Braudelian historiographic tradition became dominant in European and Latin American areas, as was indicated by authors such as Pierre Chaunu, Bartolomé Bennassar and Joseph Pérez, who, among others, employed structural analyses to establish a continuity between the lower middle ages and the modern age, delineating a line of continuity between 'reconquest' and 'conquest,' with respect to 'expansion', and strictly avoided the concept of 'empire' because it was not in keeping with the school's historiographic method (Chaunu 1955).

In the early 1950 s, a third line, this one truly Latin American-it was promoted by the OAS PanAmerican Institute of Geography and History and the journal "Revista de Historia de América", under the directorship of Silvio Zavala of Mexico-developed a 'Program of American History. For inter-American political reasons, this program was reduced to a series of historiographic summaries for each Latin American country, and ultimately to a synthesis authored by Zavala himself (1967) that contributed much to 'North-South' comparisons in the Americas and to the dissemination of the common denominator 'colonial era'. In 1985, from this genuinely American tradition, through Mexico and through the OAS the then-much-debated concept of 'encuentro de dos mundos' was launched. This concept was founded upon pre-Hispanic indigenous history and colonial history and sought to address Eurocentric viewpoints on the eve of the 500-year anniversary of Columbus' landing and to highlight the active role of the indigenous population in history. Following this line, as a result of the intense exploration of Mexican archives, from 2000 onward some essential contributions on indigenous municipalities, indigenous art and 'Indian conquistadors' emerged that recently gave rise to the well founded hypothesis that in the $16^{\text {th }}$ century the Spaniards only exercised an 'informal governance' comparable to the role played by the English in $18^{\text {th }}$ century India (Cuadriello 2004, Tanck de Estrada 2005, Matthew et a 2007, Semboloni 2007, Owensby 2008, Castro 2010, García 2011, Sembolini 2011). Following this line, for the first time 'imperial' structures were defined, derived from the concept of 'the two republics' (Spanish and indigenous), which had been conceived of long before in the field of legal history.

More or less in parallel to the 500-year anniversary of Columbus' landing, Anthony Pagden - who had studied under J. H. Elliott at Cambridge University and was influenced by the Pocock and Skinner school of discourse, also based in Cambridge - published a series of books on empire and imperialism in the modern age (Pagden 1990, Pagden 1993, Pagden 1994, Pagden 1995). These books were quickly translated into German and Spanish and distributed widely, and they mark, up to a point, the beginning of a truly imperial conjuncture. It is important to recall that David Brading, another great Americanist at Cambridge who had focused his studies primarily on Mexican archival sources, published what was at the time a monumental book, in which he firmly avoided the concept of 'empire' (Brading 1991). Nevertheless, that marked the beginning of the proliferation of 'imperial' books, accompanied by the most varied adjectives, not only in reference to Spain and Portugal and their overseas territories, but to virtually all pluriethnic historic formations. For the two cases under study here, the fusion of the concept of 'empire(s)' with that of 'Atlantic history' was particularly important, and that combination was promoted in an extensive series of annual seminars delivered specially by historian Bernard Bailyn at Harvard University (Bailyn 2005). Inspired by this fusion of concepts, in the past decade a plethora of studies on 'Atlantic empires' have been published, first in English and later in other languages as well.

In France, after an attempt at summary in Bordeaux (Bennassar et al 1989, Acerra et al 1990, Bertrand et al 2011), discussions centred on the one hand on the problem of Empire in the Americas (Gruzinski et al 1996), but the works of Serge Gruzinski became increasingly important for the problematic of 'empire'. Gruzinski's work was based on early "novohispanic" pictorial testimonials, paintings created primarily by indigenous painters under the impact of the mendicant mission, and this despite not using the concept of 'empire' in the interpretation of testimonials that offered a perspective on the impact of the 'encuentro de culturas' (Gruzinski 1994, Cuadriello 2004, Vargaslugo 2006). After making a similar point by highlighting the importance of 'musical conquest' (Turrent 1993), researchers such as Brading launched into the study of religious imaginary, especially that surrounding the Virgin of Guadalupe in Mexico, nevertheless failing to relate the topic to the problematic of 'Empire' despite the obvious thematic linkages. Thus, for example, parallel to the development of the cult of the Virgin of Guadalupe, the imperial discourse developed in Mexico, transforming 'king' Moctezuma into 'emperor', designating the Spanish kings as 'Emperors of the Indies' and situating them in a line of continuity with the 'Aztec emperors', a matter that Pagden does not expand upon (Pietschmann 2006, Pietschmann 2008, Pietschmann 2011).

At the end of the century, humanist-centred studies emerged that concerned themselves with the traditions of antiquity and with Roman imperial traditions and their study in the period of Renaissance humanism. These new studies sought to reformulate and/or update 
the idea of empire, too, in architecture and painting, as well as reformulate political aspirations. Studies along these lines tend to draw the dividing line between the Middle Ages and the Modern Era at the beginning of the $15^{\text {th }}$ century. In this way, not only the Mediterranean 'Aragonese empire' enters into the debate, but also the medieval Leonese-Castillian imperial tradition and even the medieval Holy Roman Empire with its apostille of 'Germanic Nation' added by Maximilian I, evidently already under the influence of Tacitus. This, and the influence of the traditions of Burgundy, the founders of the 'Order of the Golden Fleece' as the entity that grouped together the high nobility of Europe (De Jong et alii 2010), are tremendously significant for interpreting Charles V.

To avoid overextending ourselves here, we shall also mention some German contributions to the problematic, disregarding the works of Alfred Kohler, widely known for their Spanish translation and focused on Charles V and his brother and successor in the empire, Ferdinand, and thus on the truly 'imperial' period. Peer Schmidt (t) (2008) relates the Americas to the <universal Spanish monarchy> in the $17^{\text {th }}$ century. Damler (2008), a legal historian, published a history of the treaties of the empire. The function of geographic knowledge in governing the empire - its American part - is analyzed by Arndt Brendecke (2009), while Thomas Duve (2008) analyzes a lengthy conflict between church and state regarding their jurisdiction over marginalized social groups, also of crucial importance in defining the concept of 'empire'. For his part, Alfredo Pérez-Amador Adam (2011), in his thesis in the field of literature presented at Humboldt-Universität $\mathrm{zu}$ Berlin, addresses the juridicaltheological issues of the legitimization of the 'American enterprise.' This list covers only the most recent books referring to Spain and omits an immense general bibliography on empires, rituals, ceremonies, imagology, and more. Among these it is necessary to mention political scientist and historian Herfried Münkler (2005), who in his review of empires from antiquity to the present day develops elements to distinguish 'empires' from kingdoms and other state forms.

In Spain, the adoption of the concept of 'empire' came rather late and was limited to the period of Charles V (Rodríguez-Salgado 1992) or to studies of legal history and the history of ideas. The anniversaries of Philip II and Charles V in 1998 and 2000, in addition to producing leading-edge exhibitions in art and history, prompted an important series of monographic studies, the most outstanding examples of which include the works undertaken or directed by J. Martínez Millán and González Cuerva (2011) on the composition of the imperial and royal court(s) from Charles V to Philip III, which illuminated for the first time the central governing mechanisms beyond the classic institutional approaches focused on supreme councils. Some innovative contributions were also made through the study of chronicles, including, for example, the discovery that López de Gómara was not primarily the chronicler of Hernán
Cortés but was preparing a 'parallel life' in the style of Plutarch, comparing Hernán Cortés to the corsair Barbarossa. In 2002, Manuel Lucena Giraldo coordinated a volume of essays in a new journal on empires that is intended to be comparative. For the past eight years or so, studies have been emerging that address the generalization of the concept of empire in the English literature by authors such as Antonio Miguel Bernal (2005), Carlos Martínez Shaw and José María Oliva Melgar (2005), José Manuel Díaz Blanco (2008) and José Luis Villacañas (2008), among others. Some of these raise Anglicised concepts for discussion, others accept the Atlantic as the framework, but substitute 'empire' with 'system' or adopt empire and explain it in a German, Italian, Aragonese-Castilian line, broadly influenced by the Emperor Maximilian I, in an attempt to newly legitimize the holy empire, linking it for the first time to the complement 'of the German Nation'. This concept-supported by the rediscovery, in the $15^{\text {th }}$ century, of the text by Tacitus on 'Germania' -inspired not only the humanist-merchants of Nuremberg and Augsburg, who were very close to the Emperor Maximilian, but also Matthias Ringmann and Martin Waldseemüller, who disseminated in Lorraine the concept of 'America', aware of the formers' participation in the early Atlantic enterprises, even Luther himself. And in many aspects the concept also influenced Maximilian's grandson, the equally humanist Charles V, as Larry Silver (2008) and Guiseppe Galasso (2011) noted recently. These approaches are flanked by another line from literature written in English that links empire and the Americas with the idea of 'Rome' and the Spanish policy in Rome (Dandelet 2001, Lupher 2003, MacCormack 2007, Valdés Garcia et al 2011).

More generally, it is necessary to add an entire series of histories of historic 'frontiers' that, while they do not refer directly to the Spanish or Portuguese empires, define them indirectly as spaces that are more or less expansive and open, spaces in which cultural, political, commercial, military, social and other contacts and interactions occur among representatives of widely different cultures. These frontiers indirectly define empires precisely in those places where they do not have clearly defined borders. This phenomenon is found across virtually the entire Portuguese empire, while in the case of the Spanish empire it is also found in Europe and in North Africa, in relation to the Mediterranean (Bertrand et alii 2011) and sometimes leads to a confusion with Christian missionary zones (Castelnau-Estoile et alii 2011).

To summarise provisionally, it is evident that the concept of 'empire' has been increasingly generalized, both as a unique concept to designate the Spanish monarchy in general and as a concept used for its overseas possessions. The term is also generally used in combination with adjectives, such as 'Spanish', 'French', 'English', or 'Dutch', with a more or less national delimitation, as well as with dynastic adjectives or ones related to special characteristics, such as 'Habsburg', 'Bourbon', 
'commercial', 'imaginary', 'maritime', 'tropical' etc. The chronology (middle and modern ages/ modern only), the geographic sphere (Mediterranean and/or Atlantic/Pacific), the conceptualization (political / structural / discursive / imaginary / ceremonial / institutional), the different national historiographic lenses, and the preferred use of sources (preferably metropolitan / metropolitan-peripheral / peripheral only) produced quite varied collective visions, often contradictory at first glance and only later, in light of studies, showing themselves to be complementary; but in general these criteria do not amount to anything like a definition (for example, Fernández 2009). And the problem is exemplified by authors as renowned as J. H. Elliott, who uses 'empire' as well as 'Hispanic monarchy' and 'composite monarchy', as well as titles regarding the 'Hispanic world' for his more general works, usually without clarifying why the concepts he uses vary so much (Elliott 2008, Elliott 2006, Elliott 1992, Elliott 1989).

In regard to humanism, two recent books are worth noting that concern themselves with the history of the recovery of texts from Roman antiquity of the $15^{\text {th }}$ century and later. Two of these texts, by Tacitus and Lucretius, were discovered by Italian humanists in German monastic libraries and quickly engendered intense debates that extended across many parts of Europe. While Lucretius' De rerum natura disseminated Epicurian philosophy with its atomism and the absence of a God and was attacked by Christians in antiquity for undermining the philosophical and especially theological foundations of the Christian religion, the rediscovery of Tacitus' Germania positioned him as the 'inventor' of the Germans, the indigenous people 'since time immemorial', unvanquished by the Romans, and gave reason to cast doubt on the common Roman tradition of Christianity, the native Germans were seen as 'good barbarians', calling into question the canon of the historic vision of the Bible and the New Testament. Thus did a segment of elite humanists undermine the authority of the two universal powers - the papacy and the holy empire with a view to rebuilding their own, reduced by political realities since the $14^{\text {th }}$ century, precisely by recurring to antiquity. And modern science and historic biblical revisions were the intellectual weapons in this process.

Turning to the 'imperial' works and the closest schools of reference, these provided-on the basis of both empirical and methodological-conceptual knowledge-important contributions that could tentatively be summarised as follows:

1. The concept of empire is more generally accepted for Portugal because of the continuity of the European monarchy, from which the expansion arose, and because historic changes are generally limited to its overseas possessions, and even dynastic change over time and the attendant personal union with Spain did not substantially alter the configuration of the Portuguese empire. In Spain, in contrast, after a medieval Leonese and Castillian imperial experience, the monarchies of Leon and Castile united their dynasties after having developed in very different ways and, above all, were both already pursuing expansionist aims when the matrimonial and then personal union was forged between Joanna of Castile (known as Joanna the Mad) and Charles V. First the eastern and then the western Mediterranean formed an 'Aragonese empire' and Castile vied with Portugal as early as the late $14^{\text {th }}$ century in the Atlantic and African expansion.

2. On the other hand, the Castillian expansion under the Catholic Kings followed late medieval Iberian traditions. With Charles V, who ascended to the throne at the same time as the conquest of Mexico, 'Spain' - really 'an unfinished project' - became part of an 'empire' of universal aspirations to prolong the Holy Roman Empire, secular and humanist-inspired with many Roman adaptations that left its structural, institutional and humanist mark on "New Spain". At the same time, the conflicts with the Rome of the Curia continued, inherited partly from the Catholic Kings. Owing to the civil conflicts in Peru, only New Spain emerged organized according to the Roman model adopted by Charles V: The kingdoms lend themselves to comparison with Roman-like senatorial provinces, with cities, villas, and indigenous municipalities under separate military jurisdiction (in the hands of the Captain General) and the royal ambit under the purview of the Viceroy and the Audience (court of justice) and the ecclesiastic ambit in the hands of a bishop with a rank similar to the Viceroy. At the same time, the provinces were similar to the imperial provinces of a Roman-style military government, without cities or indigenous villages, and the governance of the Spanish cities was also in military hands, in both cases with a different governing regime for each of the 'two republics'. The system, which limited itself to mining operations and extracting indigenous tribute and lacked a mercantile ideology, resembled the imperial Roman colonization more than the modern concept of a colonial empire (Cañal 2012, Neira 2012). And neither should Spain's North African possessions be forgotten in this context-zones which Charles V even called on personally as the last Spanish king, and among which many - such as Orán, for example - were left under Spanish control until well into the $17^{\text {th }}$ century (Bunes et alii 2011). Indeed, Orán was recently described as a 'little court', while current studies on the Viceroys avoid the 'imperial' concept and speak again of 'monarchy'; the conceptual confusions appear to be increasing still. After Charles V, many aspects of the crown's policy changed, and further study is required to determine precisely to what extent things changed in the hybrid Roman imperial model adopted by Carols, and moreover, to what extent they gave rise to different realities in both Europe and the Americas, making it crucial to re-study the significance 
for the 'empire-monarchy-kingdoms' problem. To avoid overextending the subject, the following are just some of the most relevant factors applicable to the case:

3. With Phillip II and the end of the Council of Trent, the model of Charles $\mathrm{V}$ did not continue in the Americas, though it did in Europe until 1588. Inside Spain there was a policy of forced assimilation of the Moors, descriptions of the monarchy, the codification of laws and measures to protect the coasts. There were also measures from Flanders to promote the counter-reformation in the Holy Empire, the payment of pensions to Catholic princes in Germany, a growing dependency on Italian and German bankers (Fugger, repairing the mines of Almadén), and military protection for the 'Spanish road' between Italy and Flanders in the western sectors of the Holy Empire. These were all rather imperial tendencies, after all, although they must be distinguished from simple 'hegemonic predominance'. In Toledo's initial organization of Peru, Charles' concessions to the indigenous peoples were omitted (they were not allowed to establish villages or cities, and the Inca capital of Cuzco appears to have been divided in half through the central plaza, with one part indigenous and the other Spanish). More generally, there was an observable reduction in the role of the mendicant orders that sought to limit them to a monastic life, a phenomenon that was more accentuated in New Spain, while in Peru a ban on idolatry was instituted. In both viceroyalties, military conquest was prohibited and the missionary expansion was placed in the hands of the Jesuits, a new religious order with clear imperial leanings that had been richly endowed in Spain by the daughter of Charles V. Also beginning at that time was the militarization of borders and ports through the construction of defensive fortifications, to repel foreign invaders, pirates and corsairs both on the Iberian Peninsula and in the Americas. At the same time, the expansion into Asia continued from Acapulco, the port exclusively licensed for such enterprises, and the Philippines were subjugated by the Viceroy of Mexico. Also at this time, greater autonomy was granted to the viceroys after the disaster of the Armada in 1588. In the Pacific and the Philippines, the Manila-Acapulco axis was connected to that of Veracruz-Havana-Seville, forming the fastest route between Asia and Europe until the opening of the Suez Canal. Furthermore, imperial control over the north of Mexico was consolidated by the settlement of Tlaxcalteca indigenous people sent to cultivate grapevines, among other things.

4. Under Phillip III, the Moors were expelled and peace had to be made with the Dutch and German Lutherans from the north to consolidate the power of the peninsular state, while in both viceroyalties the power of the elite was consolidated through measures to extend 'imperial control', especially of the re- sources of subjugated provinces. The notion of the 'King of the Spains and Emperor of the Indies' began to be disseminated, while in Europe the beginning of a deep crisis became apparent. These tendencies continued under Phillip IV, while in the time of Charles II changes began to be apparent. Notable above all is the enactment of the Compilation of the Laws of the Indies in 1680-1, giving the Spanish Indies its first legal code, which increasingly took the place of the complex system of more limited royal norms, norms issued by American civil and ecclesiastical governors, and customs and practices legitimized by tradition and time alone, all of which had together helped to strengthen the authority of the viceroyalty capitals. Even with the mere mention of political events that either issue from or affect the political royal and viceroyal political centres of this empire (which displays different nuances over time), at each stage it is always necessary both to trace demographic movements and the transfer of personnel within this very difficult-to-define collective, and to observe the effects/impacts that the developments mentioned had on peripheral and even border areas, whether in relation to un-integrated ethnic groups or vis-à-vis the growing interference of other European powers.

\section{PORTUGUESE HISTORIOGRAPHY FROM 'DISCOVERY' TO 'EXPANSION' AND 'EMPIRE'}

In Portugal, the expansion and occupation of territories in Africa, Asia and the Americas was and is generally understood to be a process of empire formation. This point of view, marked by the imperialism of the $19^{\text {th }}$ century among others, and adopted and advanced in the 20 th century by the Portuguese 'Estado Novo' (New State), was however always a controversial issue and often was eclipsed by other concepts and/or coexisted simultaneously with them. Once decolonization occurred and interest in historic investigations to evoke the greatness of the nation waned, Portuguese dominion of the high seas earned critical attention, interpreted in relation to the concept of 'empire'. This rebirth of the concept of 'empire' as a category of investigation is valid especially for Brazil, whose economic and political prominence gave it a prominent role within the imperial structure. Given this role, it is necessary to clarify to what extent the above mentioned term 'empire' is applicable here, or to ask whether it should be changed or at least expanded - a hegemonic Portugal with a subordinated empire, with Lisbon at the centre, relegating its domain to a periphery distributed over four continents, appears to be an increasingly questionable scenario. On the other hand, a debate has recently emerged, also influenced by the latest studies (Coates 2006), that questions the extent to which the political structure that kept Portugal and its overseas possessions united could be considered an empire, and what this term can contribute in this context. 
The term 'empire' has long been accepted in research into the Portuguese world, which also demonstrates how fuzzy the concept behind the term itself is. In the classic four-volume work by Vitorino Magalhães Godinho, L'économie de l'empire portugais aux XV et XVI siècle (The economy of the Portuguese Empire in the $15^{\text {th }}$ and $16^{\text {th }}$ centuries) (1981-1983), the term appears in the original French title but not in its Portuguese translation. Godinho's work is thus situated historically between an older tradition marked by names, such as Jaime Cortesão, that labelled the Portuguese expansion overseas as 'discovery' and 'expansion', and more recent trends that at least insinuate a larger imperial political structure.

The term 'empire' had already been adopted previously by researchers outside of Portugal. From early on, literature in English-speaking countries referred to Portugal's overseas 'empire'. Seminal scholars of Portugal such as Bailey W. Diffie (1960) and George D. Winius (1977) had no qualms using the term. Their book also is the first of a ten-volume series by Shafer (1974-1977) through which the concept of 'empire' began to come into general usage in the literature in English; indeed, almost all volumes in the series bear the term 'empire' in their titles. Charles Boxer himself, the most renowned member of the first generation of English-speaking 'imperial' historiographers, has written seminal works on the topic. As the European colonial empires were crumbling in the 1960s and ' 70 s, interest increased in studying their formation, and, just four years after a work on the Dutch empire was published in 1965, even before publication of Parrys' work on Spain that quickly became a classic - the several-times published and translated book, 'The Portuguese Seaborne Empire: 1415-1825' appeared. Once the trail was blazed, another generation of authors emerged that included Anthony Disney (2009) and Malyn Newitt (2005 and 2009), who in their overall presentation of the recent era also affirmed Portuguese history as a process of empire building. This not only applies to works that are universal and therefore tend to prioritize historical-political aspects, but also to those with an expressly social and cultural historical orientation, and even works such as those by Russell-Wood (1998), which include infrastructural aspects. The imperial interpretation has been promoted at the same time in monographs, backed by a greater understanding of empire and the role corresponding in this context to proselytizing work aimed at transmitting the Christian faith and its economic facets (Alden 1996, Ames 2000). Authors in the Englishspeaking sphere, above all, haphazardly refer to a rather vague concept of 'empire' to refer to both the Portuguese's initial presence in Asia and their decline overseas beginning in the $19^{\text {th }}$ century (Clarence-Smith 1985, Wheeler 2009, Subrahmanyam 2012).

As is the case with research that focuses on the Hispanic-American world, it has not been and is not easy to implant the term used to characterize the beginnings of empire formation in studies focusing on Portugal.
The causes are essentially the same. Furthermore, in this case the Annales School exerts a great deal of influence on research of the post-WWII Portuguese empire by contemplating, from a long term perspective, the structural continuities beyond the practiced political censure of the Middle Ages and the Modern Age. Contrary to the 1957 doctoral thesis of Frédéric Mauro, the abovementioned work by Godinho, also presented at the Sorbonne as a doctoral thesis two years before Mauro's (1957), already bore the word 'empire' in the title. These texts, however, did not manage to establish a Portuguese imperial tradition in historiography, but at least the term was introduced, and along with it the reality that, compared to its Spanish counterpart, the term could coexist more peacefully with other concepts, above all when interest went beyond the initial stage of Portuguese expansion. This fact is confirmed in the wide-ranging eight-volume work published by António Henrique de Oliveira Marques and Joel Serrão 'Nova história da expansão portuguesa' (New History of Portuguese Expansion) (1986-2006). Although here, too, exactly like Jaime Cortesão's 'História da expansão portuguesa' (History of Portuguese Expansion) (1993), the leitmotif is the word 'expansion'; the first two volumes deal with the Portuguese expansion and the colonization of the Atlantic, while the subsequent volumes focus on Asia, Brazil and Africa, which are divided into regions via terms such as the 'eastern empire', 'PortugueseBrazilian empire' and 'African empire'. More than anyone, Valentim Alexandre (1993) has driven the research in this direction and has studied, from a metropolitan perspective, the empire and the threat of its breakdown after the loss of its principal colony - Brazil. This tendency has been strengthened by Paquette (2013), who does not start with the formal rupture between the two parties but, on the contrary, emphasizes the longevity of the empire in the evolution of both. In general, in the most recent publications on the topic, the parallel use of the established term of expansion and the more modern term 'empire' has been maintained, one case in point being Francisco Bethencourt and Kirti Chaudhuri's work, 'História da expansão portuguesa' (History of Portuguese Expansion) (1998-2000). Unlike in the works of Marques and Serrão, here the authors describe the beginning of the overseas advancement as 'A formação do imperio (1415-1570)' (The formation of empire) and the volumes on Brazil and the 20th century also come under the imperial signifier (Bethencourt et alii 2008). By 2008 one could interpret Portuguese history by contrasting it with that of other empires, while just one year before the editor himself had published the latest version of his study on the topic under the title 'Portuguese Oceanic Expansion, 1400-1800' (Bethencourt et alii 2007), to which one of the book's editors added the 'imperial' attribute of his own volition to the title of an historical-cultural description (Curto 2009). It remains to be seen if these occurrences indicate a trend to give the term 'empire', previously loaded with the ideological rules of the 'Estado Novo', its own category 
of investigation, substituting for older categories that are increasingly loaded themselves because of their unilateral European orientation. When all is said and done, whether this happens or not will depend not only on the degree to which an imperial concept such as this one can take hold as an analytical concept, contrasting it in a considered manner and differentiating it clearly from other concepts.

In this same regard, there have been some recent attempts that seek to integrate, above all, the so-called second Portuguese-Brazilian empire and the Portuguese metropolis. From the outset, the main focus has been on the transfer of the economic centre of the Portuguese empire to the Atlantic in the $17^{\text {th }}$ century. Special attention has also been paid to the administrative structures that regulated the existing relationship between the American and European territories, as well as the respective development of new policy areas (Fragoso et alii 2001, Bicalho et al 2005, Mello and Souza et al 2009, Schwartz et al 2009, Fragoso et al 2010). This occurred against the backdrop of the displacement of power relations that prefigured the shift of the court from Lisbon to Rio de Janeiro in 1807/08, after Napoleonic troops invaded the Iberian Peninsula (Lyra 1994, Schultz 2001).

These developments - which are only summarized here but nonetheless continue to be vital and are reinforced in several works published in recent years - deserve to be credited (as in the Spanish case), if not with joining together European and American lines of investigation, as in the Brazilian case, then at least with bringing them closer. The focus on bringing closer together not only very distant areas but the very research of these areas using 'empire' as an investigative concept - which in the case of Brazil also includes several foreign researchers, mostly from the US - has helped the investigation not only to achieve important individual results in the field of political history but also to broaden the historiographic scope of research beyond national borders. Nevertheless, this has not helped clarify the concept itself as an analytical research category to any large degree. Meanwhile, the latest works continue to be based above all on the most recent conjuncture of 'empire' and as such follow the same lines as the usual fuzzy concepts - a political structure of immense scale, often transcontinental, oriented politically, economically and also in part culturally toward a centre that itself radiates out towards the periphery. In other words, as long as commentators do not expressly identify 'empire' as a specific concept within the notion of political orders of the Modern Age, opportunities for knowledge will continue to be missed. And in response to the increase in research on empire, Antonio Manuel Hespanha (2001 and 2010) has only recently inquired into the term's effectiveness and limitations, questioning the political structure of the Portuguese empire against the backdrop of the state formation process in the Modern Age and advocating, with a view to the overseas territories, for their separation. Arguing for the need to recognize that it is not possible to adequately describe the overseas empire through the processes of centralizing bureaucratization or social discipline backed by the European model, he proposes that 'empire' in all forms could be recognized as a separate category of investigation.

These problems of definition reflect to a certain extent the wide variety of expansion programs and enterprises that characterized precisely the early $15^{\text {th }}$ and $16^{\text {th }}$ century stage and the literature on the topic in question. With regard to Portugal, it is worth mentioning a recent collection on the linkages and relations between Portugal and the Holy Roman Empire, a connection that already existed early in the $15^{\text {th }}$ century when a substantial number of Portuguese knights under the command of Infante Don Pedro, brother of Henry the Navigator, fought the Turks in the Balkans in the 1420s beside the Emperor Sigismund, while German musketeers fought on the Portuguese side in North Africa. From the dynastic union of Frederick III of Habsburg and Eleanor of Avis, sister of Alphonse VI, the future Emperor Maximilian I was born, just a few years before Constantinople fell to the Ottomans (Pohle 2000, Ramalheira 2002, Curvelo et al 2011).

Along with the political aspects of the expansion went other motives. During the reign of John II (1481-1495) particularly, the conquest of the African coast was advanced significantly: In 1482 the Portuguese reached the mouth of the Congo River, in 1486 they reached what is today Namibia, and in 1488, Bartolomeu Dias circumnavigated the Cape of Good Hope to arrive at the Indian Ocean. At the same time, John continued his plan to cross Africa over land to find the kingdom of the legendary Prester John and fight with him against the Muslims (Curto 2008). It is possible that both 'reconquests' - in the sense of the orbis christiani and the expansion of trade through the conquest of the transoceanic sphere - constituted an imperial project on John's part (Thomaz 1994). For its part, Portugal's decided advancement to the south reveals the driving force behind the empire - to reach India and in doing so enter the pepper and spice trade without the need for Arabic, Venetian, Turkish or Genovese intermediaries.

We come up against a similar problem in the case of the so-called 'State of India'. Once the Portuguese quickly got a firm foothold in Asia, these possessions were joined together under the title of the 'State of India' and ruled by a governor or viceroy. However, not even a construct such as this could hide the fact that the 'State of India' was a series of fortified trading posts that extended from the southern East African coast to the Arabian Peninsula and the Near East and the Bay of Bengal, then to Malaysia, China and beyond Southeast Asia to the Pacific Ocean, and the vast majority of them owed their existence to the tolerance or even support of local authorities. In the legal debate around the principle of mare liberum put forward by Hugo Grotius in 1609, the Portuguese Crown responded by emphasizing, last but not least, the 'empire' that it was supporting in Asia (Saldanha 1997). But the relatively quick invasion of that space, first by the Dutch and then by the British, 
demonstrates precisely that the right to a potential imperial domain of whatever kind, though perhaps desired, was not sustainable (Veen 2000).

Although afterward the Portuguese never completely renounced their imperial rights, they remained far from being realized despite the union of the two Iberian crowns from 1580 to 1640 (Cardim 2010). Since the late Middle Ages when Portuguese expansion started in the Atlantic, Portuguese incorporated the overseas experience in their mental horizon, creating thereby in the following two centuries a lasting "consciousness of empire" (Marcocci 2012). Imperial thinking also boosted when the overseas trade shifted to the Atlantic, particularly Brazil. Brazil was also the setting, at the end of the colonial era, for a kind of renovatio imperii, before it, too, separated from Lisbon once and for all to form its own empire in the early $19^{\text {th }}$ century.

At a higher level of abstraction, despite studies such as those undertaken by Pagden, it can also be said that there are still many aspects of the debate that require clarification. Questions that could be asked include: What is the influence of humanism and what contribution did it make to the erosion of the traditional parameters that postulated the unity of the western Christian world up to the beginning of the $15^{\text {th }}$ century, with a pope and an emperor as the supreme ecclesiastical and secular authorities (Greenblatt 2011, Krebs 2011)? To what extent did the critique of the Roman curia's immorality in the Renaissance and the Lutheran reform on the one hand, and the advance of the Ottomans and the impossibility of organizing a common resistance against them because of the successive urban uprisings of the late $15^{\text {th }}$ and early $16^{\text {th }}$ centuries on the other, enable the kings and princes to consolidate their power, weakening the popes and emperors of the Holy Empire? To what extent did the Atlantic expansion impact the encounter with other 'barbarian men' who fit even less into the framework of knowledge that was just then being recovered from classical antiquity, and fit in no way within the historic vision of the Bible, not to mention with the advancements in modern science driven by the process of expansion and its attendant empiricism? To what extend did Charles V's concept of the 'universal empire', formulated by his chancellor Mercurino Gattinara, represent a continuity with this process of erosion, insisting, with the 'universal' denomination, upon something that had previously gone without saying? Or was it, on the contrary, a modern concept that, with the pillars of Hercules as an insignia and Plus ultra (further beyond) as a motto, attempted to encompass these new tendencies in a universalist vision that invited the 'barbarians' to join it (Lester 2009)? And somewhat later in Spain and France, tacitism became an important aspect of self-identification, a reminder of the Visigoths and Franks that was employed to challenge the overweening influence of the Holy See in internal ecclesiastical politics. In the case of Portugal, in particular, more discussion is needed on tacitism in light of Silvio Bedini's work (1997). The process that caused 'empire' and
'Rome' to be converted into concepts that served an often antagonistic policy also needs more in-depth analysis, in light of the shift in perspective that came about in a world that was changing quickly as the news of the expansion spread through Europe (Pieper 2000). Was this a process that slowly transformed the classical Holy Roman Empire into a series of Atlantic empires (Benton 2010)? In any case, the idea of 'empire' remained in force in both the Americas and in Europe until the $19^{\text {th }}$ century and even later, but seemed to be received differently in each hemisphere (Pietschmann 2010, Pietschmann 2012).

\section{NOTES}

1. This investigation has been funded by the 'Comisión Nacional de Investigación Científica y Tecnológica' (CONICYT), 'Fondo Nacional de Desarrollo Científico y Tecnológico’ (FONDECYT), reference number: 1110643 , "Imperio y emperadores. Conceptos de orden político y espacial entre nación e independencia en Brasil (1750 - 1831)".

\section{REFERENCES}

Acerra, M. \& Meyer, J. (1990) L'empire des mers. Des Galions aux Clippers. Office du Livre.

Alden, D. (1996) The making of an enterprise: the Society of Jesus in Portugal, its empire, and beyond, 1540-1750. Stanford University Press, Stanford.

Alexandre, V. (1993) Os sentidos do império: questão nacional e questão colonial na crise do Antigo Regime português. Edições Afrontamento, Porto.

Ames, G. J. (2000) Renascent Empire? The house of Braganza and the quest for stability in Portuguese Monsoon Asia, ca. 1640-1683.Amsterdam University Press, Amsterdam.

Bailyn, B. (2005) Atlantic History. Concept and contours. Harvard University Press, Cambridge, Ma. \& London.

Bedini, Silvio A. (1998) The pope's elephant. J. S. Sanders \& Co., Nashville, TN.

Bennassar, B. et alii (1989) Le Premier âge de l'état en Espagne (1450 - 1700). (Coordination: Christian Hermann. Collection de la Maison des Pays Ibériques, vol. 41: 147-188). Éd du CNRS \& Bordeaux, Impr. Laplante, Paris.

Benton, L. (2010) A search for sovereignty. Law and geography in European empires, 1400-1900. Cambridge University Press, Cambridge.

Bernal, A. M. (2005) España proyecto inacabado. Costes/beneficios del Imperio. Fundación Carolina, Centro de Estudios Hispánicos e Iberoamericanos, Marcial Pons Historia, Madrid.

Bertrand, M. \& Planas, N. (directors), (2011) Les sociétés de frontière de la Méditerranée à l'Atlantique (XVIe-XVIIIe siècle). Casa de Velázquez, Madrid.

Bertrand, M. \& Priotti, J.-P. (directors), (2011) Circulations maritimes. L'Espagne et son empire (XVIe-XVIIIe siècle). Presses Universitaires de Rennes, Rennes.

Bethencourt, F. \& Chaudhuri, K. (directors), (1998-2000) História da expansão portuguesa. 5 vols. Círculo de Leitores, Lisboa.

Bethencourt, F. \& Alencastro, L. F. de (orgs.), (2008) L'empire portugais face aux autres empires XVI-XIX siecle. Maisonneuve \& Larose, Paris.

Bethencourt, F. \& Ramada Curto, D. (editors), (2007) Portuguese Oceanic expansion, 1400-1800. Cambridge University Press, Cambridge.

Bicalho, M. F. \& Amaral Ferlini, V. L. (orgs.), (2005) Modos de governar: ideias e prácticas politicas no império português, séculos XVI-XIX. Alameda, São Paulo. 
Boxer, C. R. (1965) The Dutch seaborne empire: 1600-1800. Hutchinson London.

Boxer, C. R. (1969) The Portuguese seaborne empire: 1415-1825. Hutchinson, London.

Brading, D. A. (1991) The First America: the Spanish monarchy, Creole patriots and the liberal state, 1492-1867. Cambridge University Press, Cambridge.

Brendecke, A. (2009) Imperium und Empirie. Funktionen des Wissens in der spanischen Kolonialherrschaft. Böhlau-Verlag, Köln \& Weimar \& Wien.

Bunes Ibarra, M. A. de, Alonso Acero, B. (coordinators), (2011) Orán. Historia de la corte chica. Ediciones Polifemo, Madrid.

Cañal, V. L. en colaboración con la Real Academia Sevillana de Buenas Letras (2012). Nueva Roma. Mitología y humanismo en el Renacimiento sevillano. Centro de Estudios Europa Hispánica, Madrid.

Cardim, P. (2010) La aspiración imperial de la monarquía portuguesa (siglos XVI y XVII). In Comprendere le monarchie iberiche: risorse materiali e rappresentazione del potere organised by Sabatini, G.: 37-72. Viella, Roma.

Castelnau-L'Estoile, C. de. et alii (2011) Missions d'èvangelisation et circulation des savoirs. Casa de Velázquez, Madrid.

Castro Gutiérrez, F. (coordinator), (2010) Los indios y las ciudades de Nueva España. UNAM, Instituto de Investigaciones Históricas, México.

Chaunu, P. \& Chaunu, H. (1955-1960) Séville et l'Atlantique, 1504-1650. 8 vols. Armand Colin, SEVPEN, Touzot, Paris.

Clarence-Smith, G. (1985) The third Portuguese empire, 1875-1975: a study in economic imperialism. Manchester University Press, Manchester.

Coates, T. J. (2006) "The Early Modern Portuguese empire: A commentary on recent studies." The Sixteenth Century Journal 37/1: 83-90.

Cortesão, J. (1993) História da expansão portuguesa. Imprensa Nacional-Casa da Moeda, Lisboa.

Cuadriello, J. (2004) Las glorias de la República de Tlaxcala o la conciencia como imagen sublime. UNAM, Museo Nacional del Arte, México.

Mota Curto, P. (2008) História dos portugueses na Etiópia (1490-1640). Campo da Letras, Porto.

Ramada Curto, D. (2009) Cultura imperial e projetos coloniais (séculos XV a XVIII). Editora Unicamp, Campinas.

Curvelo, A. \& Simões, M. (editors), (2011) Portugal und das Heilige Römische Reich (16.-18. Jahrhundert)-Portugal e o Sacro Império (séculos XVI-XVIII). Aschendorff Verlag, Münster.

Damler, D. (2008) Imperium Contrahens. Eine Vertragsgeschichte des spanischen Weltreichs in der Renaissance. Franz Steiner Verlag, Stuttgart.

Dandelet, T. J. (2001) Spanish Rome, 1500 - 1700. Yale University Press, New Haven \& London.

De Jonge, K., García García, B. J. and Esteban Estríngana, A. (editors), (2010) El Legado de Borgoña. Fiesta y ceremonia en la Europa de los Austrias (1454-1648). Fundación Carlos de Amberes, Marcial Pons Historia, Madrid.

Díaz Blanco, J. M. (2010) Razón de estado y Buen Gobierno. La guerra defensiva y el imperialismo español en tiempos de Felipe III. Universidad de Sevilla, Sevilla.

Diffie, B. W. (1960) Prelude to empire: Portugal overseas before Prince Henry the Navigator. The University of Nebraska Press, Lincoln.

Diffie, B. W. \& Winius, G. D. (1977) Foundations of the Portuguese empire, 1415-1580. University of Minnesota Press, Minneapolis.

Disney, A. (2009) A history of Portugal and the Portuguese empire. 2 vols. Cambridge University Press, Cambridge.

Elliott, J. H. (1989) Spain and its world, 1500-1700. Yale University Press, New Haven \& London.

Elliott, J. H. (1992) “A Europe of composite monarchies." In Past and Present 137: 48-71.

Elliott, J. H. (2006) Empires of the Atlantic world. Britain and Spain in America 1492 - 1830. Yale University Press, New Haven \& London.

Elliott, J. H. (2008) Un rey, muchos reinos. In J. Gutiérrez Haces (coordinator). Pintura de los reinos-Identidades compartidas.
Territorios del mundo hispánico, siglos XVI-XVIII. 4 vols. (vol. I: 40-83). Fomento Cultural Banamex, México.

Fernández Sebastián, J. (director), (2009) Diccionario político y social del mundo iberoamericano. La era de las revoluciones, 1750 - 1850. (Iberconceptos, vol. I). Fundación Carolina, Sociedad Estatal de Conmemoraciones Culturales, Centro de Estudios Políticos y Constitucionales, Madrid.

Fragoso, J., Gouvêa, M. de F. (orgs.), (2010) Na trama das redes: politica e negócios no império português, séculos XVI-XVIII. Civilização Brasileira, Rio de Janeiro.

Fragoso, J. \& Bicalho, M. F. \& Gouvêa, M. de F. (orgs.), (2001) O Antigo Regime nos trópicos: a dinâmica imperial portuguesa (séculos XVI-XVIII). Civilização Brasileira, Rio de Janeiro.

Galasso, G. (2011) Carlos Vy la España imperial. Estudios y ensayos. Centro de Estudios Europa Hispánica, Madrid.

García Martínez, B. (2011, abril-junio) "Encomenderos españoles y British residents. El sistema de dominio indirecto desde la perspectiva novohispana". Historia Mexicana, LX (4. no. 240), 1915-1978.

Greenblatt, S. (2011) The swerve. How the world became modern. W.W. Norton, New York.

Gruzinski, S. (1994) L'Aigle et la Sibylle. Fresques indiennes du Mexique, Imprimerie Nationale. Paris.

Gruzinski, S. \& Wachtel, N. (editors), (1996) Le Nouveau Monde-Mondes Nouveaux. L'expérience américaine.-Actes du colloque organisé par le CERMACA (EHESS/CNRS), Paris, 2-4 juin 1992. Ed. du CNR, Paris.

Hespanha, A. M. (2010) Antigo regime nos trópicos? Um debate sobre o modelo político do império colonial português. In J. Fragoso \& M. de F. Gouvêa (orgs.). In Na trama das redes: política e negóciosno império português séculos XVI-XVIII: 43-93. Civilização Brasileira, Rio de Janeiro.

Hespanha, A. M. (2001) A constituição do império português. Revisão de alguns enviesamentos correntes. In $O$ Antigo Regime nos trópicos: a dinâmica imperial portuguesa (séculos XVI-XVIII), edited by Fragoso, J., Bicalho, M. F. and Gouvêa, M. de F.: 163-188. Civilização Brasileira, Rio de Janeiro.

Koenigsberger, H. (1958) The Empire of Charles V in Europe. In The New Cambridge Modern History, edited by Elton, G., Vol. II: The Reformation, 1520-1559: 301-333. Cambridge University Press, Cambridge.

Koenigsberger, H. (1968) Western Europe and the Power of Spain. In The New Cambridge Modern History, edited by Wernham, R. B., Vol. III: The Counter-Reformation and Price Revolution 1559-1610: 234-318. Cambridge University Press, Cambridge.

Krebs, C. B. (2011) A most dangerous book. Tacitus's Germania from the Roman empire to the Third Reich. W. W. Norton, New York.

Lester, T. (2009) The fourth part of the world. The race to ends of the earth, and the epic story of the map that gave America its name. Free Press, New York.

Lucena Giraldo, M. (coordinator), (2002) Las tinieblas de la memoria. Una reflexión sobre los imperios en la Edad Moderna (Debate y perspectivas. Cuadernos de Historia y Ciencias Sociales 2 (2002, septiembre). Fundación Mapfre, Madrid.

Lupher, D. A. (2003) Romans in a new world. Classical models in sixteenth-century America. The University of Michigan Press, Ann Arbor, Mi.

Viana Lyra, M. de L. (1994) A utopia do poderoso império. Portugal e Brasil: bastidores da politica, 1798/1822. Sette Lettras, Rio de Janeiro.

MacCormack, S. (2007) On the wings of time. Rome, the Incas, Spain, and Peru. Princeton University Press, Princeton \& Oxford.

Magalhães Godinho, V. (1969) L'économie de l'empire portugais aux XV et XVI siècle. SEVPEN, Paris.

Magalhães Godinho, V. (1981-1983) Os descobrimentos e a economia mundial. 4 vols. Presença, Lisboa.

Matthew, L. E. \& Oudijk, M. (editors), (2007) Indian conquistadors. Indigenous allies in the conquest of Mesoamerica. University of Oklahoma Press, Norman.

Marcocci, Giuseppe. (2012) A consciência de um império: Portugal e o seu mundo, sécs. $X V$-XVII. Imprensa da Universidade de Coimbra, Coimbra. 
Martínez Millán, J. \& González Cuerva, R. (coordinators), (2011) La dinastía de los Austria: las relaciones entre la monarquía católica y el imperio (La Corte en Europa: Temas, vol. 5). Ed. Polifemo, Madrid.

Martínez Shaw, C. \& Oliva Melgar, J. M. (editors), (2005) El sistema atlántico español (siglos XVII-XIX). Marcial Pons Historia, Madrid.

Mauro, F. (1957) Le Portugal et l'Atlantique au XVIIe siècle, 1570-1670: étude économique. Université, Thèse, Paris.

Mello e Souza, L. de \& Ferreira Furtado, J. \& Bicalho, M. F. (orgs.), (2009) O governo dos povos. Alameda, São Paulo.

Münkler, H. (2005) Imperien. Die Logik der Weltherrschaft-vom Alten Rom bis zu den Vereinigten Staaten. Rowohlt, Reinbek bei Hamburg.

Neira, L. (coordinator), (2012) Civilización y barbarie. El mito como argumento en los mosaicos romanos. Creaciones Vincent Gabrielles, Madrid.

Newitt, M. (2009) Portugal in European and world history. Reaktionbooks, London.

Newitt, M. (2005) A history of Portuguese overseas expansion, 1400-1668. Routledge, London \& New York.

Owensby, B. P. (2008) Empire of law and Indian justice in Colonial Mexico. Stanford University Press, Stanford, Ca.

Pagden, A. (1990) Spanish imperialism and the political imagination. Studies in European and Spanish-American social an political theory, 1513-1830. Yale University Press, New Haven \& London.

Pagden, A. (1993) European encounters with the New World. From Renaissance to Romanticism. Yale University Press, New Haven \& London.

Pagden, A. (1994) The uncertainties of empire. Essays in Iberian and Ibero-American intellectual history. Ashgate Publishing Company, Aldershot, Brookfield.

Pagden, A. (1995) Lords of all the world. Ideologies of empire in Spain, Britain and France, c. 1500-c.1800. Yale University Press, New Haven \& London.

Paquette, G. (2013) Imperial Portugal in the age of Atlantic revolutions: the Luso-Brazilian world, c.1770-1850. Cambridge University Press, Cambridge.

Parry, J. H. (1940) The Spanish Theory of Empire in the XVIth Century. Cambridge University Press, Cambridge.

Parry, J. H. (1966) The Spanish Seaborne Empire. Hutchinson, London.

Pérez-Amador Adam, A. (2011) De legitimatione imperii Indiae Occidentalis. La vindicación de la empresa americana en el discurso jurídico y teológico de las letras de los Siglos de Oro en España y los virreinatos americanos. Iberoamericana \& Vervuert, Madrid \& Frankfurt.

Pieper, R. (2000) Die Vermittlung einer neuen Welt. Amerika im Kommunikationsnetz des habsburgischen Imperiums (1493-1598). Von Zabern Verlag, Mainz.

Pietschmann, H. (2008) Das koloniale Mexiko als Kaiserreich? Anmerkungen zu einem Forschungsproblem. In Plus ultra. Die Welt der Neuzeit, edited by Edelmayer, F., et alii, Festschrift für Alfred Kohler zum 65. Geburtstag: 487-510. Aschendorff, Münster.

Pietschmann, H. (2010) Die Verfassungsentwicklung der spanischen Monarchie im 18. Jahrhundert. In H. Neuhaus (Ed.). Verfassungsgeschichte in Europa. Tagung der Vereinigung für Verfassungsgeschichte in Hofgeismar vom 27. bis 29. März 2006 (Beihefte zu „Der Staat“, vol. 18: 27-47). Dunker \& Humblot, Berlin.

Pietschmann, H. (2010) Paralelismos y percepciones mutuas en el proceso de formación de la representación político-democrática en México y Alemania en el primer tercio del siglo XIX. In Alemania y el México independiente. Percepciones mutuas, 1810-1910, edited by Kohut, K.: 193-212. Herder, México.

Pietschmann, H. (2011) Frühneuzeitliche Imperialkriege Spaniens: Ein Beitrag zur Abgrenzung komplexer Kriegsformen in Raum und Zeit. In Imperialkriege von 1500 bis heute. Strukturen-Akteure- Lernprozesse, edited by Bührer, T., Stachelbeck, C. and Walter, D.: 73-92. Paderborn et alii: Ferdinand Schöningh.
Pietschmann, H. (2012) Diego García Panes y Antonio Joaquín de Rivadeneira Barrientos, pasajeros en un mismo barco. Reflexiones en torno al México 'imperial' entre 1755 y 1808. In Un hombre de libros. Homenaje a Ernesto de la Torre Villar, coordinated by Mayer, A.: 203-232. UNAM, México.

Pohle, J. (2000) Deutschland und die überseeische Expansion Portugals im 15. und 16. Jahrhundert. LIT-Verlag, Münster \& Hamburg \& London.

Pinhão Ramalheira, A. M. (2002) Alcácer Quibir e D. Sebastião na Alemanha. Representações historiográficas e literárias (1578-ca. 1800). Minerva Coimbra, Coimbra.

Rodríguez-Salgado, M. J. (1992) Un imperio en transición. Carlos V, Felipe II y su mundo. Editorial Crítica, Barcelona.

Russell-Wood, A. J. R. (1998). The Portuguese empire, 1415-1808: a world on the move. The Johns Hopkins University Press, Baltimore \& London.

Vasconcelos de Saldanha, A. (1997) Iustum imperium: dos tratados como fundamento do império dos portugueses no oriente. Estudo de historia e do direito internacional e do direito português. Fundação Oriente \& Macau: Instituto Português do Oriente, Lisboa.

Schmidt, P. (2012) La monarquía universal española y América. La imagen del imperio español en la Guerra de los Treinta Años (1618 - 1648). Fondo de Cultura Económica, México.

Schultz, K. (2001) Tropical Versailles: empire, monarchy, and the Portuguese royal court in Rio de Janeiro, 1808-1821. Routledge, New York \& London.

Schwartz, S. \& Myrup, E. L. (Orgs.), (2009) O Brasil no império marítimo português. Edusc, Bauru.

Semboloni, L. (2007) La construcción de la autoridad virreinal en Nueva España, 1535-1595. Tesis doctoral en prensa. El Colegio de México, México.

Semboloni, L. (2011) "Los mandamientos virreinales en la formación del órden jurídico político de Nueva España, 1535-1595". Jahrbuch für Geschichte Lateinamerikas-Anuario de Historia de América Latina, 48: 151-178.

Serrão, J. \& Oliveira Marques, A. H. de (director), (1986-2000) Nova história da expansão portuguesa. 11 vols. Estampa, Lisboa.

Shafer, B. C. (editor), (1974-1977) Europe and the world in the age of expansion. 10 vols. University of Minnesota Press, Minneapolis.

Silver, L. (2008) Marketing Maximilian. The visual ideology of a Holy Roman emperor. Princeton University Press, Princeton \& Oxford.

Subrahmanyam, S. (2012) The Portuguese empire in Asia, 1500-1700: a political and economic history. 2. ed. Wiley Blackwell, Hoboken.

Tanck de Estrada, D. (2005) Atlas ilustrado de los pueblos de Indios. Nueva España, 1800. Mapas de Jorge Luis Miranda García y Dorothy Tanck de Estrada, con la colaboración de Tania Lilia Chávez Soto. El Colegio de México, El Colegio Mexiquense, Comisión Nacional para el Desarrollo de los Pueblos Indígenas, Fomento Cultural Banamex, México.

Thomaz, L. F. (Org.). (1995) De Ceuta a Timor. DIFEL, Lindaa-Velha.

Turrent, L. (1993) La conquista musical de México. Fondo de Cultura Económica, México.

Valdés García, J. \& Ramírez Vidal, G. (Eds.). (2011). Entre Roma y Nueva España. Homenaje a Roberto Heredia Correa. 50 años de docencia. UNAM, México.

Vargaslugo, E. et alii (2006) Imágenes de los naturales en el arte de la Nueva España. Siglos XVI al XVIII. Fomento Cultural Banamex, México.

Veen, E. van (2000) Decay or defeat?: an inquiry into the Portuguese decline in Asia, 1580-1645. Research School of Asian, African, and Amerindian Studies (CNWS), Leiden University, Leiden.

Villacañas, J. L. (2008) ¿Qué imperio? Un ensayo polémico sobre Carlos V y la España imperial. Almuzara Ediciones, Córdoba.

Wheeler, D. L. (2009) Império esquecido pelo tempo: sobre como escrever uma história do império ultramarino português, 1822-1975. In S. Schwartz \& E. L. Myrup (Eds.). O Brasil no império marítimo português : 541-555. Edusc, Bauru.

Zavala, S. (1967) El mundo americano en la época colonial. 2 vols. Editorial Porrúa, México. 